DOI: $10.20472 / E S .2017 .6 .2 .004$

\title{
INCOME INEQUALITY AND SELECTED METHODS OF ITS MEASUREMENT WITH THE USE OF PRACTICAL DATA FOR INTERNATIONAL COMPARISON
}

\author{
PAVLÍNA HEJDUKOVÁ, LUCIE KUREKOVÁ
}

\begin{abstract}
:
This study defines the possible approaches which are used for the measurement and comparison of income inequality. It discusses the usability of these approaches and points to selected indicators of income inequality at the level of international comparison and also identifies the factors that cause income inequality. The aim of this study is to describe the relationship between customary indicators of inequality and an alternative indicator. Data was used from nine European countries and two data sources were combined: the OECD and ESS. The final data set contained 16686 observations. By verifying the compliance of relative frequencies, the difference between countries was demonstrated to the degree of agreement with the reduction in income inequality. The results of the test on the compliance of relative frequencies allowed us to consider the question of the monotonic trend of population relative frequency. It turned out that the rate of agreement to reduce the income gap with increasing income inequality increased.
\end{abstract}

\section{Keywords:}

Approaches, Income, Inequality, Index, Measuring, Indicators, Factors

JEL Classification: D30, D60, F60

\section{Authors:}

PAVLÍNA HEJDUKOVÁ, University of West Bohemia, Faculty of Economics, Czech Republic, Email: pahejdu@kfu.zcu.cz LUCIE KUREKOVÁ, University of Economics in Prague, Faculty of Economics, Czech Republic, Email: xkurl06@vse.cz

\section{Citation:}

PAVLÍNA HEJDUKOVÁ, LUCIE KUREKOVÁ (2017). INCOME INEQUALITY AND SELECTED METHODS OF ITS MEASUREMENT WITH THE USE OF PRACTICAL DATA FOR INTERNATIONAL COMPARISON . International Journal of Economic Sciences, Vol. VI(2), pp. 68-81., 10.20472/ES.2017.6.2.004 


\section{Introduction}

The issue of income inequality is a very sensitive one that often produces strongly conflicting views in society. However, one common view is that a certain degree of inequality is beneficial for the development of society. However, what is the appropriate rate at which income inequality can be considered optimal and where is the borderline? Unfortunately, answering this question is impossible, as it depends on the subjective assessment of each individual, a fact that can be seen in many different research studies. Income inequality is a part of social economics, which is the science that studies the impacts of economic activity and how it is shaped by social processes (Pearce, 1992).

Income inequality can be interpreted as a benchmark for the characteristics of the economies of particular states, or as a measure of poverty and welfare (Jäntti \& Danziger, 2000). However, from another point of view, it can be said that it also concerns considerable information about the structure of social and tax systems in specific countries, which is related to the issue of the redistribution of funds in society (see Perotti, 1996 or Bassett, 1999).

Studying inequalities is often the privilege of sociologists, economists, mathematicians and statisticians, who are particularly interested in how to measure, evaluate and interpret them. As mentioned by Dabla-Norris et al. (2015, p. 6) "some degree of inequality may not be a problem insofar as it provides the incentives for people to excel, compete, save, and invest to move ahead in life".

Income inequality is a very complex problem for both theory and practice. This paper begins with brief overviews of the theoretical background of inequality (the concept of inequality, selected approaches and indicators for measuring income inequality). Methodology and data are then mentioned. The paper continues with the results of the empirical study using international comparison and discussion about factors affecting income inequality. Conclusions, some suggestions for future research and points on possible limitations of the studies contained in this research area are mentioned in the end of the paper.

\section{Theoretical background}

\subsection{Definition of income and inequality}

Inequality can positively influence growth by providing incentives for innovation and entrepreneurship (Lazear \& Rosen 1981), and, perhaps especially relevant for developing countries, by allowing at least a few individuals to accumulate the minimum needed to start businesses and receive a good education (Barro 2000). On the other hand, high and sustained levels of inequality, especially the inequality of opportunity, can lead to large social costs (Stiglitz, 2012).

"When we think of income inequality, our first reaction is to think of it within the borders of a country. This is quite understandable for a world where the nation-state is very important in determining one's income level, access to a number of benefits, from 
pensions to free health care, and where by far the dominant way in which political life is organized is at the level of a country. However, in the era of globalization another way to look at inequality between individuals is to go beyond the confines of a nation-state, and to look at inequality between all individuals in the world" (Milanovic, 2012, p. 2). Therefore, it is necessary think about this topic in a broader sense, as the inequality of income is one of the many aspects of globalization.

The concept of inequality can be explained from a mathematical point of view as a distinction between two or more particular characters, provided that these characters can be quantified. From an alternative perspective, the notion of inequality is perceived by many as a lack of equal opportunity, which is determined by different circumstances that people are unable to influence (Atkinson, 2016).

From an economic point of view, inequality is the difference found in various measures of economic welfare among individuals in a group, among groups in a population, or among countries.

Income is defined as the flow of wages, interest payments, profit shares, and other valuable assets that arise over a certain period of time (usually one year) (Samuelson \& Nordhaus, 2007). Another definition of income says that income describes the flow of money flowing to households from business owners, state benefits, rental income, and more (Keeley, 2015). This means that income is a flowing quantity and consists of property income, labor income and, last but not least, government transfers (Samuelson \& Nordhaus, 2007).

\subsection{Measuring income inequality and selected indicators}

There are many indicators which are used for measuring inequality in the distribution of income. The most common measure of income inequality is derived from the Lorenz curve; Morgan (1962), however, claims that the Gini index (Gini coefficient) is the best single measure of inequality. Other classical indicators for measuring inequality in distribution of income include the coefficient of variation and Theils' index (Gaswirth, 1972). Additionally, the ratio of the share of total income earned by the poorest forty percent of the population to the share of total income earned by the richest twenty percent of the population - a measure used in both Alesina \& Rodrik (1994) and Persson \& Tabellini (1990) - is calculated. Modifications of this indicator are often used, such as the income quintile share ratio (S80/S20), the Robin Hood index or the Atkinson index (see Kennedy et al., 1996 or De Maio, 2007).

The Gini coefficient is usually defined mathematically based on the Lorenz curve (for more see Lorenz, 1905), which plots the proportion of the total income of the population ( $y$ axis) that is cumulatively earned by the bottom $x \%$ of the population (Albu, 2012; Gini, 1997). The line at 45 degrees thus represents perfect equality of incomes.

The basic idea of the Robin Hood index is to redistribute part of the income from the richer group towards the poorer group in order to achieve equality in income distribution. Compared to the Gini coefficient, which calculates only relative inequalities between households, the benefit of Robin Hood's index can be an effort to find and quantify the 
greatest difference between the absolute equity and the true distribution of income in society (Kennedy et al., 1996).

The purpose of the Atkinson index was to eliminate problems arising from the inaccurate interpretation of the Gini coefficient in the event that Lorenz curves intersect (Ryscavage, 2015). The Theil index is expressed as the weighted geometric average of the income share. Free and publicly available EasyStat software is often used for these calculations.

The coefficient of variation uses statistical characteristics, such as variance and standard deviations. The result of the coefficient of variation is a dimensionless number which, when multiplied by one hundred, expresses a relative degree of variability. An example of the issue of measuring inequality in income distribution would mean that the lower the value of the variation coefficient, the lower the income differentiation (i.e. higher equality) (Sharma, 2012).

Over time, this graphic expression has become one of the most widely used tools for assessing income inequality. The popularity of the Lorenz curve (LC) can be attributed to its clarity, especially when used, for instance, in place of numerical methods. However, when comparing multiple graphs, this advantage is lost, especially when the differences in inequalities are not very marked (Lapáček, 2008). In order to construct the Lorenz curve, it is first necessary to assign a proportional breakdown to the incomes among divided household groups and then carry out a cumulative calculation of the percentage of these two parameters expressing the $x$ and $y$ axes of the Lorenz chart. The income quintile share ratio is based on dividing persons by income earned into socalled quintiles. In statistics, the quintile is a special denomination of a quantum that expresses a value and divides the statistical set into five equal parts (OECD, 2005).

\section{Methodology and data}

In the following section of this paper, methods used to compare income inequality between individual states are described. Then, individual variables and their data sources are explained. First, income inequality is compared in selected EU countries based on two common indicators and their comparisons of average, minimum and maximum values and the development of these indicators' values over time. The Gini coefficient and the S80/S20 income quintile share ratio (further referred to as S80S20) are commonly used to express income inequality and are often published by the Organisation for Economic Co-operation and Development (OECD).

The Gini coefficient is based on the comparison of cumulative proportions of the population against cumulative proportions of income they receive, and it ranges between 0 in the case of perfect equality and 1 in the case of perfect inequality. The S80S20 refers to the ratio of average income of the top $20 \%$ in relation to the average income of the bottom $20 \%$ in terms of income distribution (the higher the S80S20, the higher the income of the richest classes of the population). 
We then focus on alternative expressions of income inequality and have therefore selected the so-called "gincdif" variable, which is meant to express the degree of agreement with reducing the differences in the amount of incomes in a given country. This variable is published by the European Social Survey (ESS) in its cross-sectional surveys. With the help of this variable, it is possible to indirectly track the degree of income inequality in selected countries. Subsequently, the compliance of relative occurrences was tested - in other words, the compliance among the shares of units possessing the characteristic in question in $r$ populations was tested. The test criterion is structured as follows:

$$
\chi^{2}=\sum_{i=1}^{r} \frac{\left(m_{i}-n_{i} p\right)^{2}}{n_{i} p(1-p)}, p=\frac{m}{n}
$$

The test statistic has a chi-squared distribution with $r-1$ degrees of freedom. Where $r$ is the number of countries (populations), $m_{i}$ is the number of occurrences of the characteristic in question in a given country (population); $n_{i}$ is the frequency of all phenomena in the given country. In our case, $r$ is equal to 9 and $p$ takes a value of 0.34 .

The results of the test on the agreement of relative frequencies allowed us to consider the question of the monotony of the trend of population relative frequency. To express the intensity of dependence of the two ordinal variables, the following association coefficients are most commonly used: gamma $(\Gamma)$, Somers' coefficients, and both of Kendall's tau coefficients. The division of these statistics is asymptotically normal and thus the share of each statistic and its standard error (SE) can be used, provided that the extent of the sample is large enough to test the independence hypothesis. In our case, this hypothesis is simultaneously a hypothesis of the non-existence of a monotonous trend of population relative frequencies. Therefore, we can prove that equality applies (see Pecáková, 2011):

$$
\frac{\Gamma}{S E(\Gamma)}=\frac{d_{x y}}{S E\left(d_{x y}\right)}=\frac{\tau_{b}}{S E\left(\tau_{b}\right)}=\frac{\tau_{c}}{S E\left(\tau_{c}\right)}
$$

The association coefficient gamma $(\Gamma)$ was used to test the hypothesis of the nonexistence of the trend.

In light of the fact that our study combines data from the OECD and ESS, our analysis was focused on countries for which complete information was available in both databases. Specifically, this dealt with nine EU member states: BEL, CZE, FIN, GBR, IRL, LTU, POL, PRT, and SVN. In studying the Gini coefficient and S80S20, we used statistical data published annually by the OECD. The period studied was from 2004 to 2014. Subsequently, the average values of these indicators were calculated. Graphs 1 and 2 show the calculated average, maximum, and minimum coefficient values measured in this period. In order to express the gincdif variable, this study uses the seventh round of the ESS, a large scale survey conducted in European countries in 2014. This variable expresses the degree of agreement with the statement: Government should reduce differences in income levels. As was mentioned above, our study is based on data from nine countries, resulting in a sample size of 16686 cases from ESS. 


\section{Results of analysis}

If we focus on the average values of coefficients calculated from data published by the OECD, it is possible to claim that heterogeneity exists among individual states.

Based on the difference in average values, we can divide these states into two groups: (i) states with a relatively even distribution of income (BEL, CZE, FIN and SVN) and (ii) states with a relatively uneven distribution of income (GBR, IRL, LTU, POL, PRT).

In countries that have a relatively even distribution of income, volatility of values in time was low; on the contrary, Gini coefficient and S80S20 values among states with more uneven income distribution fluctuated in time (see minimum and maximum values).

Generally, however, it can be claimed that a decrease in income equality took place in previous years in all the countries of the study. Only in the case of LTU is it possible to see a growth in values of both indicators. The following figures give a graphic representation (Figure 1 a Figure 2).

Figure 1: Heterogeneity among individual countries according to the Gini coefficient

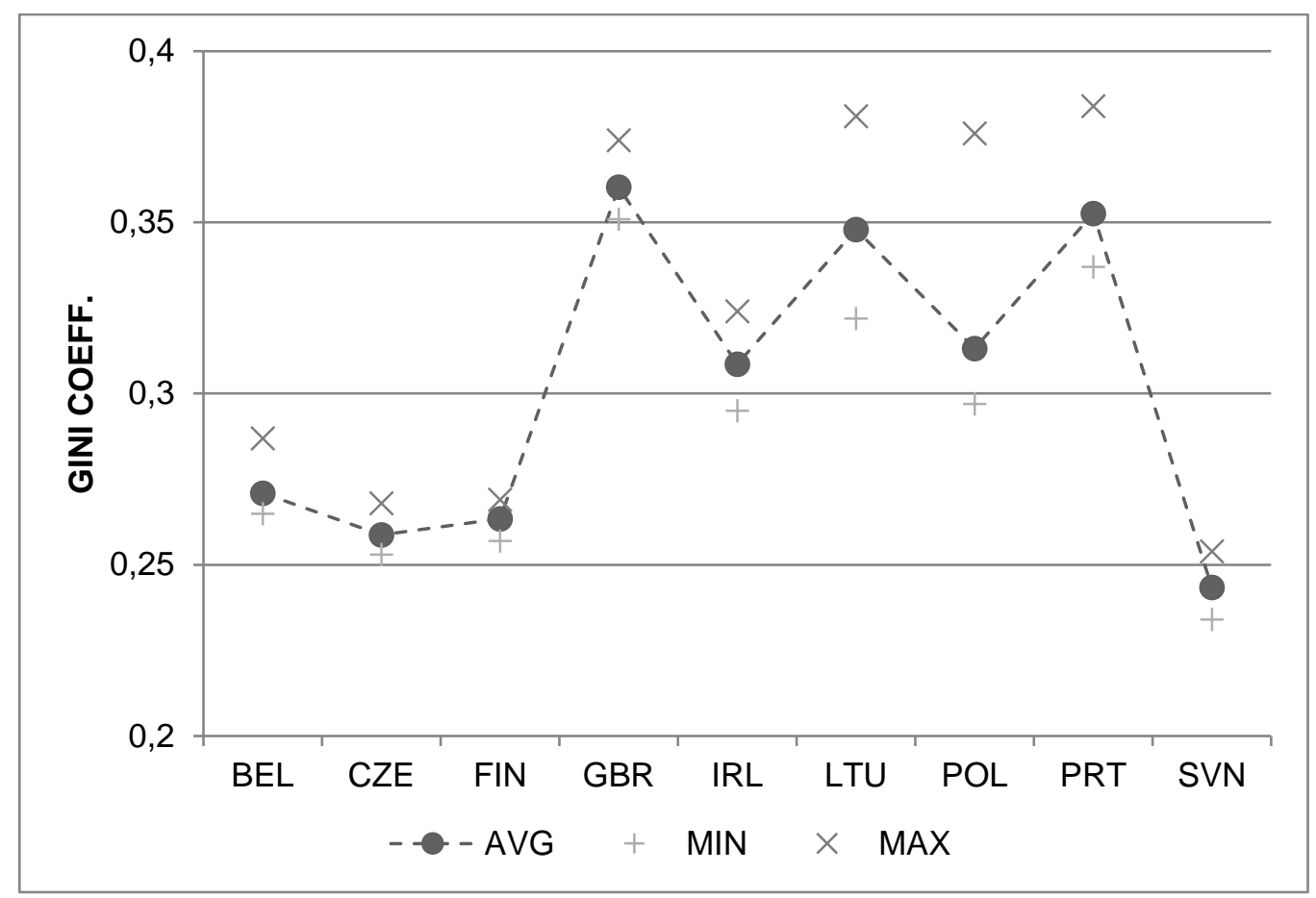

Source: OECD, 2017, own calculations 
Figure 2: Heterogeneity among individual countries according to S80/S20

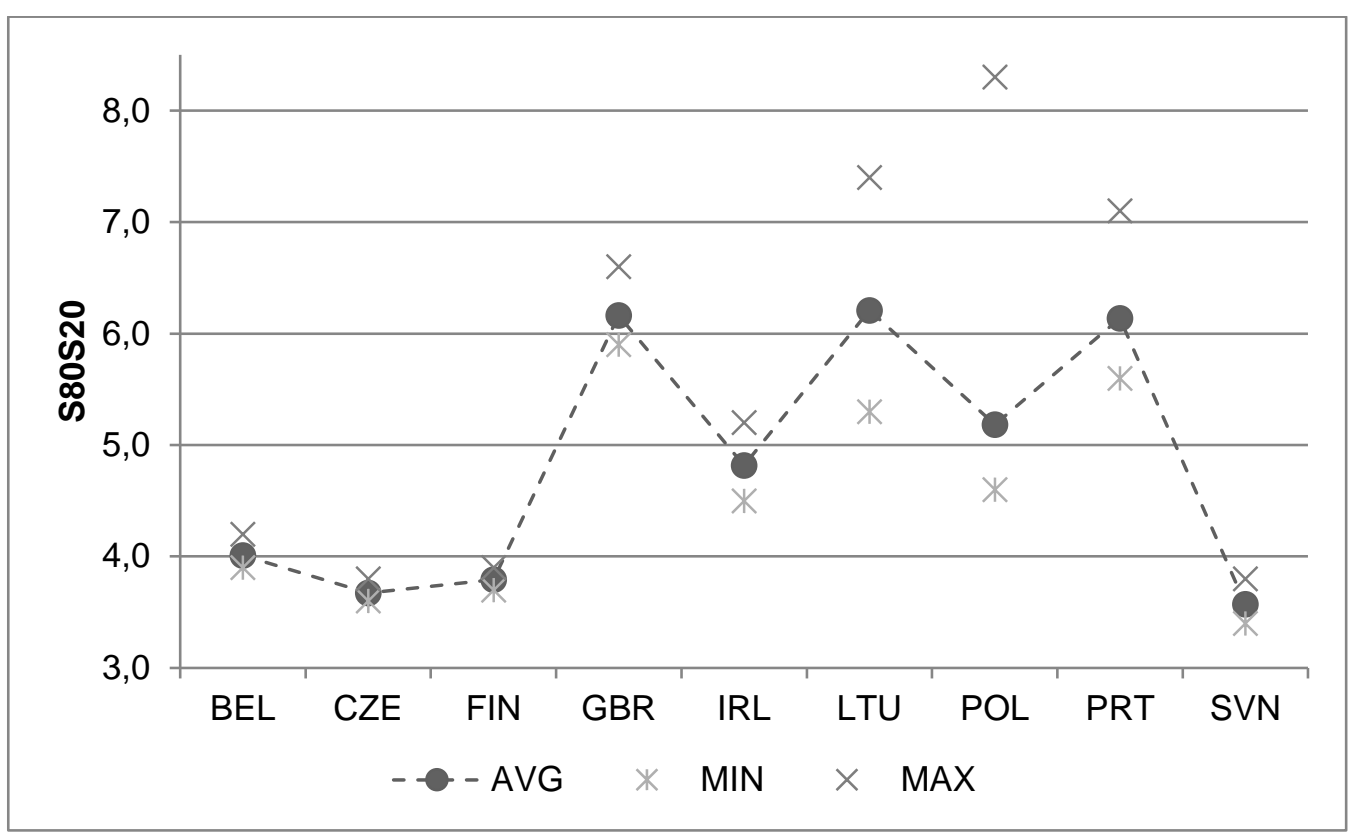

Source: OECD, 2017, own calculations

As was mentioned above, the gincdif variable from an ESS questionnaire survey was used to compare the degree of income inequality. This variable expresses the respondent's degree of agreement with the statement: Government should reduce differences in income levels. A total of 16686 respondents replied to the question. Table 1 shows the relative frequencies of replies in respective countries according to the degree of respondents' agreement. Column $\mathrm{N}$ expresses the overall number of observations in the given country. The final two columns show the order of countries according to the average Gini coefficient values reached and the S80S20 indicator from 2004 to 2014. The order of states is thus derived from the size of the average values of the Gini coefficient and S80S20 indicator ordered from the smallest average values to the largest. In other words, the final two columns show the order of countries with the lowest income inequality to countries with the highest.

Table 1: Summary of relative "gincdif" frequencies and the order of countries according to income inequality

\begin{tabular}{c|c|c|c|c|c|c|c|c}
\hline State & $\begin{array}{c}\text { Agree } \\
\text { strongly }\end{array}$ & Agree & $\begin{array}{c}\text { Neither } \\
\text { agree } \\
\text { nor } \\
\text { disagree }\end{array}$ & Disagree & $\begin{array}{c}\text { Disagree } \\
\text { strongly }\end{array}$ & $\mathbf{N}$ & GINI & S80S20 \\
\hline \hline$B E L$ & 0.2770 & 0.4347 & 0.1311 & 0.1175 & 0.0397 & 1762 & 4 & 4 \\
\hline$C Z E$ & 0.2293 & 0.3340 & 0.2448 & 0.1381 & 0.0538 & 2063 & 2 & 2 \\
\hline$F I N$ & 0.3319 & 0.3971 & 0.1580 & 0.0913 & 0.0217 & 2070 & 3 & 3 \\
\hline$G B R$ & 0.2134 & 0.4156 & 0.1951 & 0.1460 & 0.0299 & 2240 & 9 & 8 \\
\hline$I R L$ & 0.3003 & 0.4630 & 0.1268 & 0.0887 & 0.0212 & 2311 & 5 & 5 \\
\hline
\end{tabular}




\begin{tabular}{c|c|c|c|c|c|c|c|c}
\hline State & $\begin{array}{c}\text { Agree } \\
\text { strongly }\end{array}$ & Agree & $\begin{array}{c}\text { Neither } \\
\text { agree } \\
\text { nor } \\
\text { disagree }\end{array}$ & Disagree & $\begin{array}{c}\text { Disagree } \\
\text { strongly }\end{array}$ & $\mathbf{N}$ & GINI & S80S20 \\
\hline \hline LTU & 0.5126 & 0.3669 & 0.0953 & 0.0211 & 0.0040 & 2224 & 7 & 9 \\
\hline$P O L$ & 0.3954 & 0.3980 & 0.1027 & 0.0748 & 0.0292 & 1578 & 6 & 6 \\
\hline$P R T$ & 0.4306 & 0.4451 & 0.0834 & 0.0345 & 0.0064 & 1247 & 8 & 7 \\
\hline$S V N$ & 0.4324 & 0.4072 & 0.0831 & 0.0655 & 0.0118 & 1191 & 1 & 1 \\
\hline
\end{tabular}

Source: OECD, 2017, own calculations

We are primarily interested in the degree of income inequality in selected states and therefore we have focused on the reply "Agree strongly". With consideration to the fact that absolute equality in income is never likely to exist, the simple reply of "Agree" will always occur. Therefore, we assume that the "Strongly agree" reply will more likely express the degree of income inequality than the simple "Agree" answer. The test criterion for testing agreement $r$ of the relative frequencies of the selected phenomenon holds a value of 730.53. This value lies in a critical field, as the critical value is $\chi_{0,95}^{2}(8)=$ 15.5. Thus, the difference in the degree of income inequality based on the reply of "Strongly agree" was proven.

If we compare the relative frequencies of the "strong agreement" of countries within the two groups as they were previously divided according to two basic indicators, it is not at first evident whether the growth of income inequality (expressed as the order of values of the Gini coefficient or the S80S20 indicator) will lead to a growth in the degree of agreement with decreasing differences in the amount of income in a given country. For example, in Slovenia - which we included in the group of countries with relatively low income inequality - there is a relatively high occurrence of replies in strong agreement with the statement that "Government should reduce differences in income levels. On the contrary, in Great Britain (GBR), there is a relatively high level of income inequality, but only $21 \%$ of respondents strongly agree with decreasing income differences.

Based on the data listed in Table 1, we test the monotonous trend in the degree of agreement with reducing income inequality according to the order of states according to the Gini coefficient and also indicator S80S20. The association coefficient gamma $(\Gamma)$, its estimated variance and the calculated test criteria for testing the hypothesis on the non-existence of the trend are given in the following Table 2.

Table 2: Results of the monotonous trend test

\begin{tabular}{ccc}
\hline & GINI & S2080 \\
\hline \hline$\Gamma$ & -0.050 & -0.101 \\
SE & 0.008 & 0.008 \\
t-test & -6.275 & -12.675 \\
\hline
\end{tabular}

Source: ESS 2014, OECD (2017), own calculations 
For the significant level of 5\%, both values of test criteria for the Gini coefficient (-6.275) and indicator S80S20 (-12.675) are located in the critical field (critical value of -1.96). The monotony of the change in the degree of agreement with lowering income inequality was proven. The negative value of the gamma coefficient $(Г)$ means that as the ordinal number of the sample grows, the ratio of the first column of the table grows at the expense of the second column, which contains the frequencies of respondents with a strong agreement. The degree of agreement with lowering differences in income grows with heightening income inequality.

\section{Discussion on factors affecting income inequality}

A very important part of this study also includes the discussions about factors that affected income inequality. The analysis of the issue of factors influencing income inequality is mainly dealt with by studies of the OECD, which mentions this analysis in many of its publications, such as "Divided we Stand: Why Inequality Keeps Rising" (OECD, 2011) or "Income inequality: The Gap Between Rich and Poor" (OECD, 2015). Both of these reports point to the growing trend of income inequality that began in the 1980 s in most OECD countries. The study explains this trend with the example of the Gini coefficient indicator, which grew in 17 out of 22 OECD countries in the period of 1980- 2013 by almost 10\% on average (OECD, 2011; Keeley, 2015).

There are many factors that have contributed to this income inequality, which has developed to varying degrees. Among these factors, Keeley (2015) primarily ranks globalization, changes in society and employment or tax policies in various countries.

Globalization is often associated with deepening inequalities. Its basic principle is the interconnection of the world into one large, integrated society. In the context of income inequality, globalization can be explained as a wider concept for the ever greater interconnectivity of the world economy, which can be described based on several determinants including progress in technology, the liberalization of international trade and financial integration, today's increasingly fragmented International migration and many others (Keeley, 2015).

Since the end of the $20^{\text {th }}$ century much progress has been made in the field of technology. The introduction of new, effective facilities or innovations already in place has a significant impact on the labor market situation. The development of information and telecommunication technologies has a significant impact on the demand for skilled workers. Companies are looking for qualified workers, and so there are natural disadvantages (in the form of lower incomes) for those who do not understand or cannot use these technologies (OECD, 2011; Atkinson, 2016).

In recent years, the issue of international migration has also come to the forefront. This phenomenon has its fair share of supporters and opponents. The increasing share of immigrants in developed countries influences the labor market in individual countries. According to data from 2012, immigrants have contributed $70 \%$ to the growth of labor in Europe. However, studies show that there are noticeable differences in wage rates among immigrants and natives (up to $19 \%$ on average), although both groups have 
reached the same level of education. These differences may be caused by companies' inability to assess qualifications obtained in another country. Linguistic barriers or discrimination also play a significant role (OECD, 2014; 2012).

According to Keeley (2015), changes in our society or changes in workplaces also affect the deepening of inequality. Changes in society are thought to be due to the increasing tendencies of people to marry equal persons (so-called "assortative mating") either in the sense of education or in the sense of social status. In the opposite case, there is a growing number of incomplete families. Changes in the workplace are mainly changes in the structure of employment.

Significant changes in the employment structure have been recorded in the last thirty years, mainly due to a fall in full-time employment and a rise in non-traditional forms of employment, including part-time work, short-term (seasonal) employment or selfemployment. Studies show that between 1995 and 2007, these atypical forms of work accounted for even more than half of total employment (OECD, 2015; Keeley, 2015).

Another significant change in society over the past few decades is the increase in the number of single-parent families (single mothers, separation of husbands, divorce). Keeley (2015) mentions this using an example of a Nordic country where more than $25 \%$ of families are incomplete.

The third group of factors influencing the increase in income inequality includes, for example, trends in trade unions and changes in tax policy, but also factors such as liberalization in the field of worker protection or developments in product market regulation (OECD, 2011; Keeley, 2015).

Since the mid-1990s, income inequality has been on the rise. Jaumotte (2013) or Richardson (2015) notes that this situation can be caused by changes in transfers and trade.

In regard to income tax, we can generally see a reduction, but this generally leads to an increase in income inequality. Therefore, in many countries progressive taxes have been introduced. Progressive taxation means that earnings are divided into specific zones according to the level of these earning and each area is subject to different tax rates. In this case, the rule is that the higher the household income, the more this income will be taxed (Keeley, 2015; OECD, 2011).

We can find other factors affecting income inequality, but the authors consider the abovementioned factors to be the most important. In the event of interest in other research sources, we recommend the following authors: Dabla-Norris et al. (2015), Sala-i-Martin (2002) or Gottschalk \& Smeeding (1997).

\section{Conclusion}

Many specific approaches to income inequality and many indicators used in both in theory and practice exist. The available data sources for the comparison of income inequality come primarily from the OECD and the national statistical data of selected countries. 
The analytical section of this paper compares income inequality among nine selected countries of the European Union. Two indicators were used: the Gini coefficient and the S80S20 indicator from 2004 to 2014. Based on the difference in average values, we can divide the states in question into two groups: (i) countries with a relatively even distribution of income (BEL, CZE, FIN a SVN) and (ii) countries with a relatively uneven distribution of income (GBR, IRL, LTU, POL, PRT). However, in general it is possible to claim that a decrease in income inequality has been taking place in all of the states in the study in past years, with the exception of LTU, where we can see a growth in income inequality. For a further comparison of income inequality, an indicator expressing the degree of agreement with lowering differences in income was used. This indicator is related to 2014. It is published within the ESS questionnaire survey and its data set contained 16686 observations. Based on testing the agreement of relative frequencies, the difference was proven between individual countries in terms of the degree of agreement with lowering income inequality. Results of the test on the agreement of relative frequencies allowed us to consider the question concerning the monotony of the trend of population relative frequency. The degree of agreement with lowering differences in income was shown to have grown with growing income inequality.

There are many factors and limitations that affect income inequality, and therefore there are various indicators to assess it. The main fact in the eyes of the authors is that a universal methodology for measuring and comparing international and global income inequality does not exist.

No measure is perfect for the purpose of summing up income inequality. Researchers must be careful in their analysis and interpretation of results and take into account the fact that income inequality has many aspects and there are many factors that affect income inequality on an international and global level.

As mentioned by Pickett \& Wilkinson (2015), there is a very large body of literature examining income inequality, but different interpretations of the evidence and different opinions exist in both theory and practice. It is the authors' hope that the creation of this article will succeed in opening this very current topic for discussion and further research in the field.

\section{Acknowledgment}

This paper was created within the project SGS-2017-004 'Finance and Sustainable Development from the Perspective of Theory and Practice' at the University of West Bohemia, Faculty of Economics. 


\section{References}

Albu, L. L. (2012). The convergence process in the EU estimated by Gini coefficients. Journal for Economic Forecasting, 4, 5-16.

Alesina, A., \& Rodrik, D. (1994). Distributive politics and economic growth. The quarterly journal of economics, 109(2), 465-490. DOI: 10.2307/2118470.

Arnold, R. A. (2008). Economics. Mason, OH: Thomson South-Western.

Atkinson, A. B. (2016). Ekonomika nerovnosti. Brno: BizBooks.

Barro, R. J. (2000). Inequality and Growth in a Panel of Countries. Journal of economic growth, 5(1), 532. DOI: $10.1023 / \mathrm{A}: 1009850119329$.

Bassett, W. F., Burkett, J.P., \& Putterman, L., 1999. Income distribution, government transfers, and the problem of unequal influence. European Journal of Political Economy, 15, 207-228. DOI: 10.1016/S0176-2680(99)00004-X.

Dabla-Norris, M. E., Kochhar, M. K., Suphaphiphat, M. N., Ricka, M. F., \& Tsounta, E. (2015). Causes and consequences of income inequality: a global perspective. International Monetary Fund. DOI: 10.5089/9781513555188.006.

De Maio, F. G. (2007). Income inequality measures. Journal of Epidemiology and Community Health, 61(10), 849-852. DOI: 10.1136/jech.2006.052969.

ESS Round 7: European Social Survey Round 7 Data (2014). Data file edition 2.1. NSD - Norwegian Centre for Research Data, Norway - Data Archive and distributor of ESS data for ESS ERIC.

Gastwirth, J. L. (1972). The estimation of the Lorenz curve and Gini index. The review of economics and statistics, 306-316. DOI: 10.2307/1937992.

Gini, C., 1909. Concentration and dependency ratios (in Italian). English translation in Rivista di Politica Economica, 87 (1997), 769-789.

Gottschalk, P., \& Smeeding, T. M. (1997). Cross-national comparisons of earnings and income inequality. Journal of economic literature, 35(2), 633-687.

Jäntti, M., \& Danziger, S. (2000). Income poverty in advanced countries. Handbook of income distribution, 1, 309-378.

Jaumotte, F., Lall, S., \& Papageorgiou, C. (2013). Rising income inequality: technology, or trade and financial globalization? IMF Economic Review, 61(2), 271-309. DOI: 10.1057/imfer.2013.7.

Keeley, B. (2015). Income Inequality: The Gap Between Rich and Poor. OECD insights. Paris: OECD Publishing. DOI: 10.1787/9789264246010-en.

Kennedy, B. P., Kawachi, I., \& Prothrow-Stith, D. (1996). Income distribution and mortality: cross sectional ecological study of the Robin Hood index in the United States. BMJ, 312, 1004-1007. DOI: 10.1136/bmj.312.7037.1004

Lapáček, M. (2008). Solidarita, ekvivalence a přijmová nerovnost v českém sociálním systému. Fórum sociální politiky: Odborný recenzovaný časopis, 2(1), 6-13. Available at: http://www.vupsv.cz/sites/File/forum socialni politiky/Casopis FSP 1 2008.pdf 
Lazear, E. P., \& Rosen, S. (1981). Rank-order tournaments as optimum labor contracts. Journal of political Economy, 89(5), 841-864.

Milanovic, B. (2012). Global Income Inequality by the Numbers: in History and Now. An overview. The World Bank, Development Research Group, Poverty and Inequality TeamPolicy Research Working Paper 6259.

Morgan, J. (1962). The anatomy of income distribution. The Review of Economics and Statistics, 44, 270283.

OECD. (2005). Glossary of Statistical Terms - Quintiles Definition. Available at: http://stats.oecd.org/glossary/detail.asp?ID=3896

OECD. (2011). Divided We Stand: Why Inequality Keeps Rising. Paris: OECD Publishing. DOI: 10.1787/9789264119536-en.

OECD. (2012). Inequality in labour income - What are its drivers and how can it be reduced? OECD Economics Department Policy Notes, 8. Available at:: https://www.oecd.org/tax/publicfinance/49417273.pdf

OECD. (2014). Is migration good for economy? Migration Policy Debates. Available at:: http://www.oecd.org/els/mig/OECD\%20Migration\%20Policy\%20Debates\%20 Numero\%202.pdf

OECD. (2015). In It Together: Why Less Inequality Benefits All. Paris: OECD Publishing, DOI: 10.1787/9789264235120-en.

OECD.Stat. (2017). Income Distribution and Poverty. Available at:: http://stats.oecd.org/Index.aspx?DataSetCode=IDD

OECD.Stat. (2017). Income Distribution and Poverty. Available at:: http://stats.oecd.org/Index.aspx?DataSetCode=IDD

Pearce, D. W. (1992). Macmillanův slovník moderní ekonomie. Praha: Victoria Publishing.

Pecáková, I. (2011). Statistika v terénních průzkumech. Praha: Professional Publishing.

Perotti, R., 1996. Growth, income distribution, and democracy: What the data say. Journal of Economic Growth, 1, 149-187. DOI: 10.1007/BF00138861.

Persson, T., \& Tabellini, G. E. (1990). Macroeconomic policy, credibility and politics. Vol. 38, Taylor \& Francis.

Pickett, K. E., \& Wilkinson, R. G. (2015). Income inequality and health: a causal review. Social Science \& Medicine, 128, 316-326. DOI: 10.1016/j.socscimed.2014.12.031.

Richardson, J. D. (1995). Income inequality and trade: how to think, what to conclude. The Journal of Economic Perspectives, 9(3), 33-55.

Ryscavage, P. (2015). Income Inequality in America: An Analysis of Trends. Hoboken: Taylor \& Francis.

Sala-i-Martin, X. (2002). The disturbing" rise" of global income inequality. No. w8904, National Bureau of Economic Research.

Samuelson, P. A., \& Nordhaus, W. D. (2007). Ekonomie. Praha: NS Svoboda.

Sharma, J. K. (2012). Business statistics. New Delhi: Dorling Kindersley (India). 
Stiglitz, J. E. (2012). Macroeconomic fluctuations, inequality, and human development. Journal of Human Development and Capabilities, 13(1), 31-58. DOI: 10.1080/19452829.2011.643098.

Yitzhaki, S., \& Schechtman, E. (2013). The Gini methodology: A primer on a statistical methodology. New York: Springer. 